\title{
Performance and economic viability of feedlot sheep fed different levels of roughage, concentrate, and water
}

\author{
Desempenho e viabilidade econômica de ovinos confinados \\ recebendo diferentes ofertas de volumoso, concentrado e água
}

\author{
Claudete Maria da Silva ${ }^{1 *}$; Gherman Garcia Leal de Araújo ${ }^{2}$; \\ Bruna Yasnaia Souza de Oliveira ${ }^{3}$; José Augusto Gomes de Azevêdo \\ Dermeval Araújo Furtado 5
}

\begin{abstract}
The aim of this study was to evaluate performance and economic viability of producing sheep fed different levels of roughage, concentrate, and water. Forty Santa Inês crossbred sheep with an average initial weight of $18.85 \pm 2.80 \mathrm{~kg}$ and an average age of $5.0 \pm 2.0$ months were distributed in a completely randomized design with a $2 \times 2$ factorial arrangement composed of two proportions of roughage and concentrate (30:70 and 70:30) and two levels of water supply (ad libitum, and 50\% restriction), with 10 replicates. Water restriction had a negative effect $(\mathrm{P}<0.05)$ on the intakes of dry matter and nutrients and total and daily weight gains, regardless of the proportions of roughage and concentrate. Water restriction did not affect $(\mathrm{P}>0.05)$ feed conversion or feed conversion. Total weight gain, average daily gain, feed conversion, and feed efficiency were influenced by the proportions of roughage and concentrate. In conclusion, the diet with $70 \%$ roughage, associated with a water restriction of $50 \%$, reduced the uptake of energy and protein, compromising the animal performance. The combination of the diet plus concentrate and water restricted to $50 \%$ of the free consumption provides a better cost-benefit ratio.
\end{abstract}

Key words: Water intake. Feed intake. Weight gain. Water restriction.

\section{Resumo}

Objetivou-se avaliar o desempenho e a viabilidade econômica da produção de ovinos recebendo diferentes ofertas de volumoso, concentrado e água. Utilizaram-se 40 ovinos mestiços de Santa Inês, não castrados, com peso inicial de 18,85 $\pm 2,80 \mathrm{~kg}$ e idade média de 5,0 $\pm 2,0$ meses, distribuídos em um delineamento inteiramente casualizado, em um esquema fatorial $2 \times 2$, composto por duas proporções volumoso e concentrado: 30:70 e 70:30 e duas ofertas de água (água à vontade e restrito em $50 \%)$ com 10 repetições. A restrição de água causou efeito negativo $(\mathrm{P}<0,05)$ no consumo de matéria seca e nutrientes, ganho de peso total e diário, independentemente das proporções de volumoso e concentrado. Não houve efeito $(\mathrm{P}>0,05)$ da restrição de água na conversão e eficiência alimentar. $\mathrm{O}$ ganho de peso total, ganho médio diário, conversão e eficiência alimentar foram influenciados pelas proporções de volumoso e concentrado. Concluiu-se que a dieta com $70 \%$ de volumoso e associada

\footnotetext{
${ }^{1}$ Prof ${ }^{a}$ Visitante, Programa Nacional de Pós-Doutorado, Universidade Estadual Vale do Acaraú, UVA, Sobral, CE, Brasil. E-mail: claudete_m_silva@hotmail.com

2 Pesquisador, Emprapa Semiárido, Petrolina, PE, Brasil. E-mail: gherman.araujo@embrapa.br

${ }^{3}$ Discente do Curso de Doutorado em Zootecnia, Universidade Federal da Bahia, UFBA, Salvador, BA, Brasil. E-mail: brunayasnaia@hotmail.com

${ }^{4}$ Prof. Titular, Universidade Estadual de Santa Cruz, UESC, Ilhéus, BA, Brasil. E-mail. augustog@uesc.br

${ }^{5}$ Prof. Titular, Universidade Federal de Campina Grande, UFCG, Campina Grande, PB, Brasil. E-mail: dermeval@deag.ufcg.edu.br

* Author for correspondence
} 
a uma restrição hídrica de $50 \%$, reduz o aporte de energia e proteína, desfavorecendo o desempenho animal. A combinação da dieta com mais concentrado e restrição hídrica de $50 \%$ do consumo permite melhor relação custo benefício.

Palavras-chave: Consumo de água. Consumo de alimento. Ganho de peso. Restrição de água.

\section{Introduction}

Small-ruminant production is one of the main sources of income for agricultures living in the arid and semi-arid regions of the world (SALEM, 2010). In Brazil, especially in the northeast region, where the semi-arid environment predominates, smallruminant farming is an important income-generating activity, especially for small farmers. However, this region is characterized by having a hot and dry climate, with two seasons - dry and wet - with approximately 300 and $800 \mathrm{~mm}$ of precipitation per year, where the most part of rains are concentrated in three to four months during the wet season. This results in a negative water balance in most months of the year (ARAÚJO FILHO et al., 1995). Because of the soil-climatic conditions of the northeast region, extensive animal production systems tend to be inefficient due to the low availability of food and water in the dry season, leading animals to deficient food consumption and water restriction, which may affect their growth and weight gain.

In regions where water resources are scarce, animals are subjected to water restriction. Kataria (2000) stated that in order to evaluate the problem faced by animals in field conditions, the experimental model of subjecting animals to different levels of water supply is one of the ways to understand the problem. Brazilian semi-arid sheep producers deal with water scarcity, because precipitation in that region is low - on average $431.8 \mathrm{~mm}$ annually (BELTRÃO et al., 2005) - and thus animals may be susceptible to water restriction. Under such conditions, raising sheep in the feedlot may be an alternative to make the production system viable in these areas, coupled with more energetic feeding programs and diets that promote weight gain and carcass quality, with greater productive efficiency.
Animals have access to water in three main ways: free or supplied water; water contained in the food; and metabolic water. The metabolic water is formed from the oxidation of the nutrients obtained from the foods and from the catabolism of body tissues. The amount of water formed from the oxidation in the body depends on the type of feedstuff metabolized, and the catabolism of $1 \mathrm{~kg}$ of fat, carbohydrate, and protein produces 1.1, 0.5, and $0.4 \mathrm{~L}$ of water, respectively (CSIRO, 2007). The oxidation of these organic compounds leads to the formation of water from the present hydrogen (KING, 1983). Fat produces more metabolic water due to its high hydrogen content (SCHMIDT-NIELSEN, 1972).

In this regard, it is expected that the use of higher proportions of concentrate in the diet, for increasing the energy levels and providing greater amounts of soluble carbohydrates, when oxidized in the rumen, will supply a larger amount of metabolic water to animals. Thus, even with little availability of water, or below their requirements, animals will not have their performance impaired.

Energy is essential to support all vital body processes, including respiration, circulation, muscle activity, maintenance of body temperature, metabolic processes, among other functions (FREITAS et al., 2006). However, when the use of concentrates in an animal feeding program is elevated, if the energy level is increased, the production cost rises; hence why the analysis of economic viability is important for describing all details of the production chain and seeking the necessary alterations for greater production efficiency. In view of this scenario, this study aimed to evaluate the performance and economic viability of producing Santa Inês crossbred sheep receiving different levels of roughage, concentrate, and water. 


\section{Material and Methods}

The experiment was conducted on the Caatingabiome experimental field of the Animal Nutrition section of Embrapa Semiarid, located in PetrolinaPE, Brazil, in the São Francisco mesoregion (376 $\mathrm{m}$ approximate altitude; 9'23'35' $\mathrm{S}$ latitude and $40^{\circ} 30^{\prime} 27^{\prime}$ "W longitude). The clime is a tropical semiarid type, with summer rains and an average annual precipitation of $431.8 \mathrm{~mm}$ (BELTRÃO et al., 2005).

Forty uncastrated Santa Inês crossbred sheep with an average initial weight of $18.85 \pm 2.80 \mathrm{~kg}$ and an average age of 5.0 \pm 2.0 months were used. Before the beginning of the experiment, animals were weighed, dewormed for parasite control, intramuscularly injected a vitamin-mineral supplement (organic modifier Vallée), and identified for the random allocation in the treatments. Animals were confined in an open shed, in individual $1 \mathrm{~m} \times 2$ $\mathrm{m}$ stalls provided with trough and drinker.

A completely randomized design was adopted, with a $2 \times 2$ factorial arrangement composed of two proportions of roughage and concentrate in the diet (30:70 and 70:30), with 2.67 and $2.10 \mathrm{Mcal} /$ $\mathrm{kg}$ metabolizable energy, and 14.08 and $10.58 \%$ crude protein (dry matter basis), respectively, plus $1 \%$ mineral salt (Table 1). Water was supplied ad libitum (100\%) and restricted (50\%), and the experiment lasted 73 days. Diets were formulated to provide gains of 200 and $150 \mathrm{~g} /$ day, according to the NRC (2007) tables, for roughage:concentrate ratios of 30:70 and 70:30, respectively.

Soybean meal, ground corn, and Tifton hay were used in the formulation of the diets. Feed was supplied in two daily meals, at $08 \mathrm{~h} 30$ and $15 \mathrm{~h} 30$, allowing for 5 to $10 \%$ as orts. Orts were weighed daily to control the intake of dry matter and other nutrients by the animals. Samples of feeds supplied and orts were collected weekly. Animals were weighed at the beginning, weekly, and at the end of the experiment for their weight gain and feed conversion to be monitored. The chemical composition of orts, diets, and diet ingredients were analyzed for determination of dry matter (DM), organic matter $(\mathrm{OM})$, mineral matter $(\mathrm{MM})$, and ether extract (EE), as described in AOAC (1990); protein, by the Kjedahl method; and NDFap and ADF, according to Van Soest (1991)'s methodology. Table 1 shows the participation of the ingredients and chemical composition of the experimental diets.

Table 1. Participation of ingredients and chemical composition of the experimental diets in $\%$ of dry matter.

\begin{tabular}{lrr}
\hline \multirow{2}{*}{\multicolumn{1}{c}{ Ingredient }} & \multicolumn{2}{c}{ Roughage:Concentrate } \\
\cline { 2 - 3 } & $30: 70$ & $70: 30$ \\
\hline Soybean meal (\%) & 13,86 & 5,94 \\
Tifton hay (\%) & 29,7 & 69,3 \\
Ground corn (\%) & 55,44 & 23,76 \\
Mineral Salt (\%) & 1 & 1 \\
\hline Dry matter (\%) & 87,79 & 89,82 \\
Organic matter (\%) & 95,42 & 93,28 \\
Minera matter (\%) & 4,57 & 6,72 \\
Crude protein (\%) & 14,08 & 10,58 \\
Ether extract (\%) & 1,83 & 0,92 \\
NDFap (\%) & 40,96 & 55,31 \\
ADF (\%) & 25,46 & 50,89 \\
Total carbohydrates (\%) & 76,24 & 80,3 \\
NFC (\%) & 24,99 & 35,28 \\
Lignin (\%) & 1,02 & 4,82 \\
Hemicellulose (\%) & 27,19 & 29,86 \\
Cellulose (\%) & 12,75 & 20,64 \\
TDN (\%) & 73,0 & 56,0 \\
DE (Mcal/kg of DM) & 3,22 & 2,60 \\
ME (Mcal/kg of DM) & 2,64 & 2,13 \\
\hline
\end{tabular}

NDFap $=$ neutral detergent fiber corrected for ash and protein, $\mathrm{ADF}=$ acid detergent fiber, $\mathrm{TC}=$ total carbohydrates, $\mathrm{NFC}=$ non fibrous carbohydrates, TDN $=$ total digestible nutrients, $\mathrm{ME}=$ metabolizable energy.

Two levels of water were supplied, as follows: ad libitum (control) and $50 \%$ of the amount consumed when it was available freely. To adjust the restriction of $50 \%$, the live weight of the animals receiving water freely (control) was used as reference, i.e., a group of animals fed a larger 
proportion of concentrate in the diet received water ad libitum, and in the other group of animals receiving the same diet, half of the amount of water ingested by the animals from the control group was served, referencing the same live weight of each animal. The amount of water supplied to the unrestricted group was $5 \mathrm{~L}$, and this amount was supplied always in the morning. The water served and left over from the previous day by the unrestricted group was weighed daily. Water losses by evaporation were determined by placing buckets with water in different locations in the shed, and then on the next day the amount of water that had evaporated was recorded. The average evaporated water value was $0.468 \mathrm{~mL} /$ day, and this value was deducted in the calculation of water consumption of the animals from the unrestricted group. The free water intake (FW) was calculated as the difference between the water supplied minus the leftovers. Total water intake (TW) was calculated as the sum of the free water intake (FW) plus the intake of water from the feed (FWF).

To determine the economic viability of production, the total production cost, or expense, was considered, based on calculation methods proposed by Hoffmann et al. (1987). Expenses included the cost of all resources and services utilized in the production process during its activity. In the calculation of the expenses, spending with feeding (hay, corn, and soybean), mineral salt, and purchase of the animals were included. The adopted values were those quoted in the regional market.

The water cost was calculated considering the price paid for the $\mathrm{m}^{3}$ of water as $\mathrm{R} \$ 3.92$, according to a survey conducted by Compesa (Sewerage Company of Pernambuco State). The total water intake by the animals in the performance evaluation period was calculated. Values were converted to $\mathrm{m}^{3}$ and then multiplied by their price quoted in the municipality. The gross income refers to the price of all products obtained during the activity, calculated by multiplying the price of the cold carcass from each treatment by $\mathrm{R} \$ 12.00$ (price paid in the region per kilogram of meat). Net income refers to the profit obtained in the production system, calculated as the difference between gross income and expenditure (total production cost). The costbenefit ratio $(\mathrm{C} / \mathrm{B})$ was also calculated. The costbenefit ratio analysis is a rational way of deciding whether a given business is viable in certain market conditions. If $\mathrm{C} / \mathrm{B}$ is higher than 1 , the project is desirable, because the benefits generated are greater than the costs (HOFFMANN et al., 1987). The costbenefit ratio is calculated as $\mathrm{C} / \mathrm{B}=$ Net revenue/ Total diet cost.

Performance data were analyzed by the procedures of analysis of variance. The study was carried out to check if the assumptions of normal distribution, additivity, and homoscedasticity of the data were met.

The statistical model utilized in the analysis of the data is described below:

$\mathrm{Yijk}=\mu+\mathrm{E}(\mathrm{Xi}-X)+\mathrm{A}(\mathrm{Xj}-X)+\mathrm{EA}(\mathrm{Xij}-X)+\varepsilon i j \mathrm{k}$

where: Yijk = observed value of the trait;

$\mu=$ overall mean;

$\mathrm{Ei}=$ effect relative to the proportions of roughage and concentrate ( $i=30: 70$ and 70:30), considering $\mathrm{Xi}=$ observed value of the co-variable and $X=$ mean of the co-variable;

$A j=$ effect relative to the water availability $(j=$ restricted, ad libitum), considering $\mathrm{Xj}=$ observed value of co-variable and $X=$ mean of the co-variable;

EAij $=$ of the proportions of roughage and concentrate $\mathrm{i}$ and water availability $\mathrm{j}$, considering $\mathrm{Xij}=$ observed value of the co-variable and $X=$ mean of the co-variable;

Eijk $=$ random error associated with each observation Yijk.

The obtained data were subjected to analysis of variance (Proc GLM), using the Statistical Analysis System (SAS INSTITUTE, 2002), by the F test, 
adopting 0.05 as the critical level of type-I error probability. The initial body weight was adopted as a co-variable for the performance variables.

\section{Results and Discussion}

An effect $(\mathrm{P}<0.05)$ of water restriction was detected on final weight and total and daily weight gains of the animals (Table 2); however, no effects were observed on feed conversion and feed efficiency. This may likely be because the Santa Inês crossbreds were efficient in the use of the nutrients, withstanding the water restriction because of their adaptability to semi-arid region, without, however, altering their feed conversion or feed efficiency. According to Abioja et al. (2010), with a reduction in water intake, the ingested feed is retained in the rumen for longer periods than when animals consume water ad libitum, resulting in a higher digestibility, with better use of the feed and better feed conversion. This process possibly also occurred in the animals of the present study. Water restriction may improve the feed conversion rate. In goats, water restriction had a significant effect on feed conversion (ABIOJA et al., 2010), which was better in the animals subjected to the highest level of water restriction (67\%), versus the restriction levels of 0 and $33 \%$.

Table 2. Performance of Santa Inês crossbred sheep according to the levels roughage, concentrate, and water supply.

\begin{tabular}{|c|c|c|c|c|c|c|c|c|}
\hline \multirow[t]{2}{*}{ Variable } & \multicolumn{2}{|c|}{$\begin{array}{c}\text { Roughage:Concentrate } \\
\text { R:C }\end{array}$} & \multicolumn{2}{|c|}{ Water (\%) } & \multicolumn{3}{|c|}{ P Value } & \multirow[t]{2}{*}{ MSE } \\
\hline & $30: 70$ & $70: 30$ & 100 & 50 & $\mathrm{R}: \mathrm{C}$ & Water & $\mathrm{R}: \mathrm{C} \times$ Water & \\
\hline IW (kg) & 18,30 & 19,41 & 18,77 & 18,94 & - & - & - & - \\
\hline FW (kg) & 30,99 & 28,92 & 31,09 & 28,82 & 0,0326 & 0,0401 & NS & 0,54 \\
\hline TG (kg) & 12,69 & 9,51 & 12,30 & 9,88 & 0,0004 & 0,0046 & NS & 0,52 \\
\hline DW (g) & 201,43 & 150,93 & 195,22 & 156,83 & 0,0004 & 0,0046 & NS & 8,22 \\
\hline $\mathrm{FC}$ & 4,09 & 5,55 & 4,79 & 4,88 & 0,0002 & NS & NS & 0,21 \\
\hline FE & 0,25 & 0,19 & 0,22 & 0,22 & $<.0001$ & NS & NS & 0,01 \\
\hline
\end{tabular}

$\mathrm{IW}=$ Initial weight, $\mathrm{FW}=$ Final weight, $\mathrm{TG}=$ Total gain, $\mathrm{DW}=$ daily weight gain, $\mathrm{FC}=$ Feed conversion, $\mathrm{FE}=$ feed efficiency, $\mathrm{MSE}$ $=$ mean standard error.

The total and daily weight gains were affected by the water restriction (Table 2); however, this gain agreed with the $150 \mathrm{~g}$ /day recommended by NRC (2007) for the same weight range, for animals consuming $780 \mathrm{~g}$ of dry matter. With an intake lower than $780 \mathrm{~g}$ of dry matter (724.55 g/d, Table 3), the animals under water restriction obtained gains above $150 \mathrm{~g}$ /day. This demonstrates the potential of Santa Inês crossbred sheep in the semi-arid regions, which, despite receiving lower levels of water than required, were efficient in utilizing the diets for weight gain. 
Table 3. Intakes of dry matter, nutrients, and metabolizable energy by Santa Inês crossbred sheep according to the levels roughage, concentrate, and water supply.

\begin{tabular}{|c|c|c|c|c|c|c|c|c|}
\hline \multirow[t]{2}{*}{ Intake } & \multicolumn{2}{|c|}{$\begin{array}{c}\text { Roughage:Concentrate } \\
\text { R:C }\end{array}$} & \multicolumn{2}{|c|}{ Water $(\%)$} & \multicolumn{3}{|c|}{ P Value } & \multirow[t]{2}{*}{ MSE } \\
\hline & $30: 70$ & $70: 30$ & 100 & 50 & $\mathrm{R}: \mathrm{C}$ & Water & R:C x Water & \\
\hline DM (g/day) & 804,50 & 795,75 & 879,44 & 724,55 & NS & 0,0002 & NS & 21,64 \\
\hline $\mathrm{DM}\left(\mathrm{g} / \mathrm{kg}^{0,75} /\right.$ day $)$ & 72,62 & 72,92 & 78,80 & 67,04 & NS & $<.0001$ & NS & 1,49 \\
\hline DM (\% LW/day) & 3,26 & 3,29 & 3,53 & 3,04 & NS & $<.0001$ & NS & 0,06 \\
\hline $\mathrm{OM}$ (g/day) & 769,04 & 748,35 & 833,31 & 687,29 & NS & 0,0002 & NS & 20,56 \\
\hline CP (g/day) & 113,40 & 85,75 & 108,16 & 90,73 & $<.0001$ & 0,0007 & NS & 4,45 \\
\hline $\mathrm{EE}$ (g/day) & 18,11 & 15,00 & 18,12 & 14,99 & $<.0001$ & $<.0001$ & NS & 0,51 \\
\hline NDFap (g/day) & 221,68 & 450,79 & 380,25 & 300,15 & $<.0001$ & $<.0001$ & NS & 17,68 \\
\hline $\mathrm{ADF}$ (g/day) & 105,80 & 203,57 & 171,94 & 140,73 & $<.0001$ & 0,0008 & NS & 9,09 \\
\hline TC (g/day) & 641,09 & 648,90 & 710,04 & 583,39 & NS & 0,0001 & NS & 17,19 \\
\hline NFC (g/day) & 419,41 & 198,11 & 329,79 & 283,24 & $<.0001$ & 0,0030 & NS & 12,44 \\
\hline TDN (g/day) & 679,91 & 548,45 & 670,77 & 557,13 & $<.0001$ & 0,0003 & NS & 16,37 \\
\hline $\mathrm{ME} \mathrm{Mcal} / \mathrm{kg}$ of DM & 2,46 & 1,98 & 2,43 & 2,01 & $<.0001$ & 0,0311 & NS & 0,04 \\
\hline
\end{tabular}

$\mathrm{DMI}=$ dry matter, $\mathrm{LW}=$ live weight, $\mathrm{OMI}$ - organic matter, $\mathrm{CP}=$ crude protein, $\mathrm{EE}=$ ether extrcat, NDFap $=$ neutral detergent fiber corrected for ash and protein, $\mathrm{ADF}=$ acid detergent fiber, $\mathrm{TC}=$ total carbohydrates, $\mathrm{NFC}=$ non fibrous carbohydrates, $\mathrm{TDN}=$ total digestible nutrients, $\mathrm{ME}=$ metabolizable energy.

Total weight gain, average daily gain, feed conversion, and feed efficiency were influenced $(\mathrm{P}<0.05)$ by the proportions of roughage and concentrate, with the best feed conversion and highest feed efficiency found in the animals that received the diet with highest amount of concentrate. The diet with the highest level of concentrate provided higher intakes of $\mathrm{CP}, \mathrm{EE}$, and TDN, and more production of fermentable energy by the rumen microorganisms, leading to an increased microbial protein synthesis and an increase in the amount of protein available to the animal (SAYED, 2009), thereby resulting in greater weight gains and better feed conversion rates.

No interaction was found $(\mathrm{P}>0.05)$ between the proportions of roughage and concentrate and the water supply levels on any of the evaluated variables. Thus, the variables have been presented and discussed separately according to the proportions of roughage and concentrate and the levels of water supply. The intakes of dry matter (g/day, $\mathrm{g} / \mathrm{kg}^{0.75}$ and $\% \mathrm{LW} /$ day) and organic matter $(\mathrm{g} /$ day) were not influenced $(\mathrm{P}>0.05)$ by the proportions of roughage and concentrate in the diet (Table 3); however, the water restriction affected $(\mathrm{P}<0.05)$ these intakes, and this occurred probably due to the lower water availability in the reticulorumen, with an insufficient amount of water for the transport from the gastrointestinal tract and lower dilution of the ruminal content available for digestion. Moreover, digestive processes such as chewing, rumination, digestion, absorption, and excretion produce heat, and consequently animals reduce their dry matter intake in an attempt to reduce endogenous heat production during these activities (AHMED; ABDELATIF, 1994).

Water restriction has been reported to reduce feed intake in sheep and goats. Reducing water supply to sheep to $50 \%$ of ad libitum consumption, More et al. (1983) observed a reduction of $26 \%$ in feed intake, while Ahmed and Abdelatif (1994) observed that the water restriction at $46 \%$ of ad libitum consumption reduced dry matter intake by 
$40 \%$ in desert sheep; in the present study, dry matter intake decreased by $17 \%$.

The proportions of roughage and concentrate did not influence $(\mathrm{P}>0.05)$ the intake of dry matter expressed in grams per day, in percentage of live weight, and per metabolic weight. The obtained values, expressed in grams per day, are close to NRC (2007) recommendations. This observation does not mean that the uptakes of the other nutrients are also similar, since the compositions of these diets are highly different, especially regarding the energy, protein, and fiber contents. Thus, even if the variable dry matter intake is the main reference to evaluate the uptake of nutrients, these may vary according to the chemical quality of the diets.

The nutrient intakes were affected $(\mathrm{P}<0.05)$ by water restriction (Table 3 ), with a decrease caused by the lower dry matter intake by the sheep. Water is important in the transport and assimilation of nutrients and in the hydrolysis of proteins, fat and carbohydrates, and when it is insufficient for these processes, the body's likely response is a reduction in the uptake of these nutrients, starting with reduced dry matter intake (ALAMER, 2009).

For the animals with unrestricted and restricted access to water, the total digestible nutrients (TDN) intake was 670.77 and $557.13 \mathrm{~g} /$ day, respectively, whereas the intakes of metabolizable energy (ME) were 2.43 and $2.01 \mathrm{Mcal} / \mathrm{kg} \mathrm{DM}$, respectively. These values are above the TDN and ME intakes of $\mathrm{g} /$ day and $1.91 \mathrm{Mcal} / \mathrm{kg} \mathrm{DM}$ recommended by NRC (2007), considering gains of $150 \mathrm{~g} /$ day by sheep with an average weight of $20 \mathrm{~kg}$, and hence the weight gain achieved with their diet (Table 2).

The intakes in grams of CP, EE, NDFap, ADF, NFC, TDN, and metabolizable energy in Mcal $/ \mathrm{kg}$ of $\mathrm{DM}$ were influenced $(\mathrm{P}<0.05)$ by the proportions of roughage and concentrate; the highest intake of nutrients and metabolizable energy was found with the diet containing the highest proportion of concentrate. The greater intake of ether extract and crude protein by the sheep fed the diet with $30 \%$ roughage and $70 \%$ concentrate is a result of their higher amount of concentrate feed relatively to roughage (Table 1), which led to higher intakes of TDN and ME.

The intake of NDFap was higher for the sheep fed the highest proportion of roughage in the diet, because it is present in a larger amount in this feed, and because of the physical mechanism that predominates in animals on roughage diets, i.e., intake tends to increase, since the energy density is low, but its limitation occurs by the filling effect. Nevertheless, water restriction reduced NDFap intake (Table 3), which is associated with the reduced amount of water for the processes of moistening of the feed bolus, transport of the gastrointestinal content, and digestion, absorption, and removal or excretion of undigested residues, consequently limiting dry matter intake (ABIOJA et al., 2010).

The proportion of roughage and concentrate in the diet influenced $(\mathrm{P}<0.05)$ the intakes of free water (FW), water from the feed (FWF), and total (TW) for the analyzed units (Table 4). The group of animals that received diets with a larger amount of concentrate consumed more free water, and this occurred probably because those diets were more energetic, providing a higher intake of crude protein (Table 3), since high-protein foods result in a greater water requirement as a consequence of the heat increment from the protein and elimination of residues from the metabolism (SILVA, 2011). Neiva et al. (2004) also found higher water intake by Santa Inês sheep when they were fed diets with a higher amount of concentrate. 
Table 4. Water intake by Santa Inês crossbred sheep according to the levels roughage, concentrate, and water supply.

\begin{tabular}{|c|c|c|c|c|c|c|c|c|}
\hline \multirow[t]{2}{*}{ Intake } & \multicolumn{2}{|c|}{$\begin{array}{c}\text { Roughage:Concentrate } \\
\text { R:C }\end{array}$} & \multicolumn{2}{|c|}{ Water (\%) } & \multicolumn{3}{|c|}{ P Value } & \multirow[t]{2}{*}{ MSE } \\
\hline & 2,67 & 2,10 & 100 & 50 & $\mathrm{R}: \mathrm{C}$ & Water & $\mathrm{R}: \mathrm{C} x$ water & \\
\hline FW (kg/day) & 2,26 & 1,93 & 2,77 & 1,43 & 0,0014 & $<.0001$ & NS & 0,12 \\
\hline $\mathrm{FW}$ (ml/PV $0,75 /$ day $)$ & 205,12 & 177,17 & 249,15 & 133,14 & 0,0050 & $<.0001$ & NS & 10,56 \\
\hline WIF (g/dia) & 116,18 & 100,71 & 118,99 & 97,90 & 0,0050 & 0,0002 & NS & 3,26 \\
\hline WIF (ml/PV ${ }^{0,75} /$ day) & 10,48 & 9,23 & 10,66 & 9,05 & 0,0011 & $<.0001$ & NS & 0,24 \\
\hline TWI (kg/day) & 2,38 & 2,03 & 2,88 & 1,53 & 0,0010 & $<.0001$ & NS & 0,12 \\
\hline TWI (ml/PV ${ }^{0,75} /$ day) & 215,26 & 186,40 & 259,81 & 141,84 & 0,0041 & $<.0001$ & NS & 10,73 \\
\hline
\end{tabular}

$\mathrm{AL}=$ Free water $\mathrm{FW}, \mathrm{TWI}=$ Total water intake, $\mathrm{WIF}=$ water intake in food.

The diet with the largest amount of concentrate provided an additional intake of $15.47 \mathrm{~g}$ of water from the feed, because this diet contained more water in its composition (Table 1). The dietary management through variations in the ratios between concentrate and roughage, as well as the processing methods (hay and silage), influence the amount of water present in the feeds ingested by animals, which can contribute in situations in which limited water is available to them. According to NRC (2007), there is a correlation between dry matter intake and water intake, and for every kilogram of dry matter consumed, the animal must ingest $2.87 \mathrm{~L}$ of water. According to the obtained results, for the average intake of $804 \mathrm{~g}$ of dry matter (Table 2) the animal consumed $2.3 \mathrm{~L}$ of water per day, i.e., a little more than the $2.11 \mathrm{~L}$ estimated by NRC (2007) for animals consuming the same amount of dry matter. With the diet with the lowest level of concentrate, for the sheep consuming $795 \mathrm{~g}$ of dry matter, water intake should be $2.07 \mathrm{~L} /$ day, and thus the animals from our study consumed less than necessary: 1.93 L. Therefore, it should be stressed that the water intake may be influenced by other factors like breed, quality of the feed supplied, ambient temperature, live weight, and age.

Considering the water requirement published by NRC (2007), animals subjected to water restriction consumed less than what they require, and thus they were under water deficit. However, they showed similar feed conversion and feed efficiency (Table 2 ), probably due to the quality of the feed offered and the characteristics of Santa Inês crossbred sheep, which are adapted to the semi-arid region. Because the intake of free water and water from the feeds was higher in the group of animals consuming a larger amount of concentrate, the total water intake was consequently also higher. The water contained in the feeds is an important source for the animal, and represents an additional and more important source for animals reared in arid and semi-arid regions with low access to water.

The economic analysis demonstrates that the total feed cost (TFC) was higher in the group of animals fed diets containing more concentrate (30:70), because soybean and corn are more expensive than hay (Table 5). Similar results were reported by Dantas et al. (2008), who studied different levels of supplementation in the finishing of sheep and found a higher feed cost when animals received more concentrate in their diet. Although the diet with $70 \%$ of concentrate ingredients was the most expensive, it was found that the animals displayed higher final weight and total and daily gains and the best carcass yields, corroborating results reported by Pereira et al. (2010), who supplied diets with four levels of metabolizable energy and observed that weight gain was increased as the energy content of the diet was increased; however, no differences were found in carcass yield. 
Table 5. Costs of production of Santa Inês crossbred sheep according to the levels roughage, concentrate, and water supply.

\begin{tabular}{|c|c|c|c|c|}
\hline \multicolumn{5}{|c|}{ Costs of ingredients of diets in $\mathrm{R} \$ / \mathrm{kg}$ natural matter $(\mathrm{NM})$} \\
\hline Hay & \multicolumn{4}{|c|}{0,20} \\
\hline Soy & \multicolumn{4}{|c|}{1,03} \\
\hline Corn & \multicolumn{4}{|c|}{0,68} \\
\hline Mineral salt & \multicolumn{4}{|c|}{1,48} \\
\hline \multicolumn{5}{|c|}{ Forage:Concentrate } \\
\hline & \multicolumn{2}{|c|}{$30: 70$} & \multicolumn{2}{|c|}{$70: 30$} \\
\hline & Water ad libitum & Restricted water & Water ad libitum & Restricted water \\
\hline \multicolumn{5}{|c|}{ Quantities consumed ( $\mathrm{kg}$ of $\mathrm{NM})$} \\
\hline Hay & 190,39 & 155,65 & 428,55 & 355,70 \\
\hline Soy & 88,85 & 72,63 & 36,73 & 30,49 \\
\hline Corn & 355,39 & 290,53 & 146,93 & 121,96 \\
\hline Mineral salt & 6,41 & 5,24 & 6,18 & 5,13 \\
\hline \multicolumn{5}{|c|}{ Costs $(\mathrm{R} \$)$} \\
\hline Hay & 38,07 & 31,13 & 85,71 & 71,14 \\
\hline Soy & 83,35 & 74,82 & 37,83 & 31,40 \\
\hline Corn & 194,23 & 174,33 & 88,16 & 73,17 \\
\hline Mineral salt & 9,49 & 7,76 & 9,15 & 7,60 \\
\hline Total cost diet & 325,15 & 288,02 & 220,84 & 183,31 \\
\hline Cost os animals & 800,0 & 800,0 & 800,0 & 800,0 \\
\hline Cost water & 8,52 & 4,57 & 7,37 & 3,72 \\
\hline Vaccines & 5,50 & 5,50 & 5,50 & 5,50 \\
\hline Total cost & 1139,17 & 1098,09 & 1033,71 & 992,79 \\
\hline \multicolumn{5}{|c|}{ Variables } \\
\hline IW (kg) & 18,27 & 18,3 & 19,3 & 19,6 \\
\hline FW (kg) & 32,39 & 29,6 & 29,8 & 28,1 \\
\hline TG (kg) & 14,27 & 11,27 & 10,53 & 8,49 \\
\hline DW (g) & 226 & 179 & 167 & 135 \\
\hline CC $(\%)$ & 46 & 46,3 & 43,3 & 44,02 \\
\hline $\mathrm{CW}(\mathrm{kg})$ & 13,45 & 13,24 & 11,59 & 11,47 \\
\hline Total carcass $(\mathrm{kg})$ & 134,45 & 132,4 & 115,9 & 114,7 \\
\hline \multicolumn{5}{|c|}{ Financial indicators } \\
\hline GI & 1613,40 & 1588,8 & 1390,8 & 1376,40 \\
\hline $\mathrm{NI}(\mathrm{R} \$)$ & 474,23 & 490,71 & 357,09 & 383,61 \\
\hline C/B (NI/TCD) & 1,46 & 1,70 & 1,00 & 2,09 \\
\hline
\end{tabular}

$\mathrm{IW}=$ Initial weight, $\mathrm{FW}=$ Final weight, $\mathrm{TG}=$ Total gain, $\mathrm{DW}=$ daily weight gain, $\mathrm{CC}=$ cold carcass yield, $\mathrm{CW}=$ cold carcass weight, $\mathrm{GI}=$ gross income, $\mathrm{NI}=$ net income, $\mathrm{C} / \mathrm{B}=$ cost-benefit ratio, $\mathrm{TCD}=$ total cost diet.

Regarding the financial indicators, the gross income $(\mathrm{kg}$ of carcass $\times$ price $/ \mathrm{kg}$ of meat sold in the local market) was superior for the group fed the diet with greater participation of concentrate and water ad libitum $(\mathrm{R} \$ 1,613.40)$. This result was due to the higher weight of carcass obtained, and the gross income was lower when water was restricted and when the diet was composed of $70 \%$ roughage $(\mathrm{R} \$$ 
1,376.40). Because the consumption of ingredients was lower by the group of animals with restricted water, it resulted in a lower production cost with the diets, and hence higher net income or pure profit of R\$ 490.71 and R\$ 383.61, respectively, for the roughage:concentrate ratios of 30:70 and 70:30. For the same proportions of roughage and concentrate, net income was R $\$ 474.23$ and 357.09 when water was available ad libitum.

The results of the cost-benefit ratio reveal that the best return was achieved with the group of animals subjected to $50 \%$ water restriction and fed more roughage (Table 5), in which every $\mathrm{R} \$ 1.00$ invested in sheep production with restricted water and $70 \%$ roughage and $30 \%$ concentrate yielded a return of $\mathrm{R} \$ 2.09$, despite the lower daily weight gain compared with animals fed water ad libitum. For the diet with more concentrate and restricted water, the return was $\mathrm{R} \$ 1.70$. Therefore, water restriction promotes a better cost-benefit ratio in diets with different proportions of roughage and concentrate.

\section{Conclusions}

Diets with $70 \%$ concentrate associated with $100 \%$ water supply increase energy and protein intake, promoting better performance. On the other hand, diets with $70 \%$ roughage associated with a water restriction of $50 \%$ reduces the uptake of energy and protein, impairing the animal performance; however, the combination of the diet with less concentrate and $50 \%$ water restriction provides a higher net income and better cost-benefit ratio.

\section{Acknowledgments}

The authors would like to thank Universidade Federal da Paraíba (UFPB), Empresa Brasileira de Pesquisa Agropecuária (EMBRAPA) and Coordenação de Aperfeiçoamento de Pessoal de Nível Superior (CAPES) for the financial support.

\section{References}

ABIOJA, M. O.; OSINOWO, O. A.; ADEBAMBO, O. A.; BELLO, N. J.; ABIONA, J. A. Water restriction in goats during hot-dry season in the humid tropics: feed intake and weight gain. Archivos de Zootecnia, Córdoba, v. 59, n. 226, p. 195-203, 2010.

AHMED, M. M. M.; ABDELATIF, A. M. Effects of restriction of water and food intake on thermoregulation, food utilization and water economy in desert sheep. Journal Arid Environments, Londres, v. 28, n. 2, p. 147153, 1994.

ALAMER, M. Effect of water restriction on lactation performance of Aardi goats under heat stress conditions. Journal Arid Environment, Londres, v. 59, n. 1, p. 71-84, 2009.

ARAÚJO FILHO, J. A. Manipulação da vegetação lenhosa da caatinga para fins pastoris. Sobral: EMBRAPA-CNPC, 1995. 18 p. (EMBRAPA-CNPC. Circular técnica, 11).

ASSOCIATION OF OFFICIAL AGRICULTURAL CHEMISTS - AOAC. Official methods of the association of the agricultural chemists. $15^{\text {th }}$ ed. Washington: Editora Arlington, 1990, v. 2, 1117 p.

BELTRÃO, B. A.; MASCARENHAS, J. D. E. C.; MIRANDA, J. L. F.; SOUZA JUNIOR, L. C.; GALVÃO, M. J. T. G.; PEREIRA, S. N. Projeto cadastro de fontes de abastecimento por água subterrânea, Estado de Pernambuco: diagnóstico do Município de Itambé. Recife: Ministério de Minas e Energia, 2005. 22 p.

COMMONWEALTH SCIENTIFIC AND INDUSTRIAL RESEARCH ORGANISATION - CSIRO. Nutrient requirements of domesticated ruminants. Collingwood: CSIRO Publishing, 2007. $270 \mathrm{p}$.

DANTAS, A. F.; PEREIRA FILHO, J. M.; SILVA, A. M. A.; SANTOS, E. M. dos; SOUSA, B. B. de; CÉZAR, M. F. Características da carcaça de ovinos Santa Inês terminados em pastejo e submetidos a diferentes níveis de suplementação. Ciência e Agrotecnologia, Lavras, v. 32, n. 4, p. 1280-1286, 2008.

FREITAS, J. A.; QUEIROZ, A. C.; DUTRA, A. R.; VIEIRA, R. A. M.; LANA, R. de P.; LEONEL, F. de P.; HENRIQUE, D. S.; LIMA, A. V.; SOUZA, J. C. Eficiência de utilização da energia metabolizável em bovinos Nelore puros e cruzados submetidos a quatro níveis de concentrado na ração. Revista Brasileira de Zootecnia, Viçosa, MG, v. 35, n. 3, p. 894-901, 2006.

HOFFMANN, R.; ENGLER, J. J. de C.; SERRANO, O.; THAME, A. C. de M.; NEVES, E. M. Administração da empresa agrícola. 5. ed. São Paulo: Pioneira, 1987. 325 p. 
KATARIA, N. Hormonal and renal regulation of fluid retention in dromedary camel. 2000. Thesis, Ph.D. (PhD in physiology) - Faculty of Veterinary Physiology, C. C. S. Haryana Agricultural University, Hisar, India.

KING, J. M. Livestock water needs in pastoral Africa in relation to climate and forage. Research Report edn. Addis Ababa: International Livestock Centre for Africa (ILCA), 1983. 1108 p.

MORE, T.; HOWARD, B.; SIEBERT, B. D. Effect of level of water intake on water, energy and nitrogen balance and thyroxine secretion in sheep and goats. Australian Journal of Agricultural Research, Oxford, v. 34, n. 4, p. 441-446, 1983.

NATIONAL RESEARCH COUNCIL - NRC. Nutrient requirements of small ruminants: sheep, goats, cervids and new world camelids. Washington, DC.: National Academy Press, 2007. 384 p.

NEIVA, J. N. M.; TEIXEIRA, M.; TURCO, S. H. N.; OLIVEIRA, S. N. P.; MOURA, A. A. A. N. Efeito do estresse climático sobre os parâmetros produtivos e fisiológicos de ovinos Santa Inês mantidos em confinamento na região Litorânea do Nordeste do Brasil. Revista Brasileira de Zootecnia, Viçosa, MG, v. 33, n. 3 , p. 668-678, 2004.

PEREIRA, E. S.; PIMENTEL, P. G.; FONTENELE, R. M.; MEDEIROS, A. N.; REGADAS FILHO, J. G. L.; VILLARROEL, B. S. Características e rendimentos de carcaça e de cortes em ovinos Santa Inês, alimentados com diferentes concentrações de energia metabolizável. Acta Scientiarum Animal Sciences, Maringá, v. 32, n. 4, p. 431-437, 2010.
SALEM, H. B. Nutritional management to improve sheep and goat performances in semiarid regions. Revista Brasileira de Zootecnia, Viçosa, MG, v. 39, p. 337-347, 2010. Suplemento Especial.

STATISTICAL ANALYSIS SYSTEM INSTITUTE SAS Institute. SAS/STAT User's guide version 8.0. Cary: SAS Institute, 2002. 291 p.

SAYED, A. B. N. Effect of different dietary energy levels on the performance and nutrient digestibility of lambs. Veterinary World, Rajkot District, v. 2, n. 11, p. 418-420, 2009.

SCHMIDT-NIELSEN, K. Fisiologia animal. São Paulo: Edgard Blucher, 1972, 139 p.

SILVA, J. F. C. Mecanismos reguladores de consumo. In: BERCHIELLI, T. T.; VAZ PIRES, A.; OLIVEIRA, S. G. (Ed.). Nutrição de ruminantes. Jaboticabal: Funep, 2011. p. 57-79.

VAN SOEST, P. J.; ROBERTSON, J. B.; LEWIS, B. A. Methods for dietary fiber, neutral detergent fiber, and nonstarch polysaccharides in relation to animal nutrition. Journal of Dairy Science, Bethesda, v. 74, n. 10, p. 35833597, 1991. 
